\title{
Os Indígenas na Província de São Pedro: entre práticas e discursos
}

Karina Moreira Ribeiro da Silva e Melo*

Resumo: Este artigo levanta questões relevantes acerca dos processos históricos que os indígenas da Província de São Pedro viveram, levando em conta alguns dos discursos que foram produzidos por tais histórias e seus agentes. Os discursos de políticos sobre eles parecem ser contraditórios, mas mostram a dificuldade daqueles que os escreveram em lidar tanto com a política indígena quanto com a política indigenista. Diferentes, embora marcados por algumas semelhanças, os discursos dos religiosos demonstram o desafio que a prática da catequese representou para eles e para os índios. Houve razões bastante distintas para tais ações, deixando transparecer que as experiências coletivas e individuais dos índios, dos políticos e religiosos geraram conflitos e alianças importantes nas histórias dessas personagens. Palavras-chave: Província de São Pedro. Indígenas. Autoridades políticas. Missionários. Práticas e discursos.

\section{Breve passeio pelo contexto da produção dos discursos}

O século XIX foi um período de grandes transformações e contradições políticas. As tensões decorrentes da mudança de regimes políticos e os renovados propósitos econômicos oriundos da ascensão do capitalismo refletiam as disparidades da época. A política indigenista, assim como a política de 'povoamento' do Brasil, foi marcada pela preocupação com a questão da terra como um dos

\footnotetext{
* Doutoranda no Programa de Pós-Graduação em História Social da Universidade Estadual de Campinas (Unicamp), sob a orientação do Prof. Dr. John Manuel Monteiro. Bolsista do CNPq. E-mail: karinaemelo@hotmail.com
} 
principais meios para erigir a nação. Com a criação do Estado nacional brasileiro, tornava-se necessário construir uma memória nacional que reunisse a sociedade em torno de novas identidades históricas e culturais. Nesse cenário, os discursos históricos e identitários de políticos, religiosos e intelectuais sobre os índios se contradiziam e evidenciavam as disputas presentes na elaboração da história, da memória coletiva e da identidade da nação (ALMEIDA, 2007, p. 192-212). Enquanto o jovem Estado nacional brasileiro buscava autoestima e símbolos identitários que incorporassem grupos étnicos presentes em seu território, alguns grupos indígenas lutavam para continuar existindo enquanto uma coletividade em meio às políticas de assimilação e de extermínio.

Durante o Oitocentos, intelectuais que inauguraram a ciência histórica construíram um discurso que restringiu todos os grupos indígenas a dois grandes blocos estanques. Tal discurso via nos Tupis do século XVI a gênese daquilo que foi tido como autenticamente nacional, o índio. A grande contradição estava no fato de ser preciso lidar na prática com um ancestral histórico que as teorias da época comprovaram como 'cientificamente' inferior. A saída encontrada foi veicular a ideia de que existiam, no século XIX, duas categorias de índios: o índio Tupi, um herói ancestral admirado, que fazia parte de um passado nobre e distante; e o índio Tapuia, que fazia parte do presente, era desprezado e devia ser combatido (MONTEIRO, 2001). Afinal, a nação brasileira não poderia ser uma civilização reconhecida se ainda mantivesse habitantes selvagens em seu território.

De acordo com John Monteiro, os protagonistas da construção dos ideais da nova nação eram desafiados por duas ordens de questões que diziam respeito ao destino das populações indígenas. Uma, de caráter científico e antropológico, antagonizava princípios universais do Iluminismo à ciência da desigualdade, pautada em noções de raça. A outra, de cunho político, punha em choque a necessidade de valorizar as 'origens' indígenas da nação brasileira e o olhar negativo sobre o índio da atualidade. Era preciso, minimamente, conciliar a mestiçagem biológica e cultural da sociedade com a civilização da nação brasileira. Assim, (Idem, p. 131): 
[...] o resultante diálogo entre o pensamento científico e a política indigenista produziu, ao longo do século XIX e, de certo modo, do XX, imagens e opiniões conflitantes, ora promovendo a inclusão das populações indígenas no projeto da nação, ora sancionando sua exclusão. Se ambas estas questões circulavam basicamente no âmbito dos gabinetes científicos e dos gabinetes políticos, elas esbarravam, o tempo todo, nas práticas e percepções dos protagonistas dos encontros e confrontos entre índios e não índios em remotos sertões.

Mas como os indígenas teriam agido frente à prática desses discursos e como eles teriam influenciado suas histórias na Província de São Pedro? Serão necessários muitos estudos etno-históricos para esboçar uma resposta a essa pergunta. A proposta aqui é oferecer alguns apontamentos sobre essa questão, enfocando as relações de sociedade e poder estabelecidas pelos índios com os demais agentes sociais através dos discursos políticos e eclesiásticos produzidos sobre eles ao longo do século XIX. Para tanto, é preciso perceber que, mesmo estando afastada da capital do Império, portanto, longe dos gabinetes centrais da política e da ciência, conforme salientado por John Monteiro (MONTEIRO, 2001) 2 a Província de São Pedro recebia suas influências e as adaptava aos seus próprios gabinetes e sertões. Como parte da nação, ela participou da elaboração de discursos históricos, políticos e identitários sobre os índios que ocuparam seu território. Políticos e religiosos expressaram ideias e opiniões acerca dos indígenas com os quais se relacionaram. Seus discursos revelam a existência de diferentes tipos e trocas de experiências entre essas personagens históricas.

As principais fontes utilizadas são os Relatórios de Presidente da Província ${ }^{3}$ entre os anos de 1832 e 1863, a obra intitulada Comentário Eclesiástico do Rio Grande de São Pedro do Sul desde 17374, conhecida como Ementário, e as correspondências da Diretoria Geral dos Índios e dos Aldeamentos entre os anos de 1849 e $1858^{5}$. É preciso salientar que este artigo se refere aos índios na Província de modo geral, embora existam diferenças nos discursos dos padres missionários e dos políticos em relação à aplicação das políticas indigenistas para os índios guaranis e para outras parcialidades como os coroados, como far-se-á notar adiante. 


\section{Práticas indígenas nos discursos eclesiásticos}

Em 1956, o Jornal Correio do $\mathrm{Povo}^{6}$ anunciava com grande júbilo a criação do Instituto Estadual do Livro, bem como o plano de suas atividades, entre as quais a reedição de obras raras e esgotadas que tratam da história do Rio Grande do Sul. Entre esses trabalhos, havia um inédito: o Ementário Eclesiástico do Rio Grande de São Pedro do Sul desde 1737, de autoria do arcediago Vicente Zeferino Dias Lopes? O Ementário é um manuscrito de 253 páginas e foi concluído em 1891. Segundo os dizeres desta matéria, publicada em 22 de setembro de 1956 pelo historiador militar Paranhos Antunes, "O Ementário em apreço é um verdadeiro cimélio pelas valiosas informações que contém", pois o arcediago Lopes havia consultado ${ }^{8}$ :

[...] inúmeros documentos hoje desaparecidos, arquivos eclesiásticos e do governo, cartórios, Livros de Tombo das paróquias, além de ter mantido correspondências com quase todos os vigários das freguesias do Rio Grande [...]. Nosso desejo seria anotar o Ementário, de vez que nele está a história das nossas primeiras vilas e cidades [...].

A matéria terminava com um apelo que, em "ligeiras e despretensiosas linhas" lembrava aos diretores do Instituto Estadual do Livro que incluíssem também em seus programas a edição de "memórias inéditas antigas sobre o nosso Rio Grande do Sul" ". Na parte intitulada 'Paróquias', o Ementário traz informações inéditas e importantes sobre as relações de sociabilidade estabelecidas entre indígenas, moradores das vilas, autoridades políticas e eclesiásticas. Dados sobre o contexto da formação de vilas e aldeamentos, bem como a relação estabelecida entre os indígenas e autoridades do governo estão presentes na obra. Sobre a origem da cidade de Rio Pardo, o arcediago escreveu (EMENTÁRIO [1891], p. 38-46) ${ }^{10}$ :

Este território então fronteiro, [...] por ordem do Capitão General Gomes Freire de Andrada foi designado em 1750 para estabelecimento de armazéns e depósitos de munições de guerra [...]. Para os guardar na eminência, hoje conhecido 
pelo nome Alto da Fortaleza, levantou-se uma trincheira ou Forte chamado de Jesus Maria José [...]. Em pouco tempo formou-se uma povoação composta de famílias brancas. A estas famílias agregou-se depois uma porção de índios extraviados de alguns dos sete povos jesuíticos; os quais se arrancharam em quatro pequenos aldeamentos; um chamado São Lourenço - nas imediações do atual cemitério do lugar denominado Potreiro de N. Senhora, junto a um regato que hoje conserva aquele nome; outro de Santo Angelo, no alto onde está criada a casa de caridade, o qual por muitos anos deu nome a rua hoje chamada General Andrade Neves; outro de São Miguel, onde se fez a casa de pólvora; finalmente o de São Nicolau, para onde o governador José Marcelino de Figueiredo fez recolher todos os índios, e os regularizar a 22 de outubro de 1769.

O aldeamento de São Nicolau do Rio Pardo, onde o governador José Marcelino buscou reunir índios provenientes de vários lugares, foi um dos mais importantes espaços territoriais para os guaranis na Província de São Pedro. Após a guerra Guaranítica (1754-1756), num contexto marcado por situações envolvendo litígios fronteiriços, cerca de 700 famílias de índios transmigraram de alguns dos povos de Missões para Rio Pardo, mediante acordo estabelecido entre autoridades coloniais, como Gomes Freire de Andrade, e lideranças indígenas, fundando em 1757 o aldeamento. Novas fronteiras territoriais, sociais e culturais continuaram a ser construídas durante todo o período de sua perenidade. São Nicolau do Rio Pardo foi extinto na década de 1860. Em seu território, houve inúmeros acontecimentos que influenciaram a vida e o destino não somente de seus habitantes, mas aspectos importantes da própria história da Província de São Pedro. Ele foi o aldeamento que mais esteve envolvido em guerras e conflitos gerados em torno das lutas por controle territorial entre indígenas, autoridades do governo e particulares. Foi também o único que conseguiu exercer certo domínio sobre suas terras junto às esferas políticas da época provincial, assegurando que aquele espaço fosse eminentemente indígena ao longo dos três primeiros quartéis do século XIX. Fatos 
como esses não teriam ocorrido sem a ação dos índios. As estratégias acionadas por eles para alcançarem seus intentos se deu através de escolhas e posicionamentos políticos e sociais diante das situações de dificuldade e oportunidade com as quais se depararam. Isso pode ser percebido pela observação das providências tomadas pelos índios em relação a um espaço que foi constantemente acionado por eles, a igreja do aldeamento de São Nicolau do Rio Pardo, (Idem, p. 138):

A 12 de outubro de 1812 os índios obtiveram licença do Visitador Padre Agostinho José Mendes dos Reis para que o padre José Alexandre de Borba, que era capelão por eles, lhes administrasse os sacramentos do batismo, penitência, extrema unção, e também o matrimônio depois dos cônjuges se habilitarem perante o vigário da Vara de Rio Pardo. Com a morte do capelão terminou a graça, e os índios ficaram sujeitos ao vigário de Rio Pardo. Este lugar está hoje despovoado, e nele vivem ainda alguns descendentes dos primitivos habitantes, e decaiu principalmente depois que a Lei provincial $\mathrm{n}^{\mathrm{o}} 1114$ de 21 de novembro de 1860 extinguiu o aldeamento. Existe a capela sempre reformada, e velhos ornamentos; e no único altar uma bela imagem de São Nicolau, uma de N. S. da Conceição doada por Antônio José de Moura, e outra do Espírito Santo, havendo várias na Sacristia feitas pelos índios, mas imperfeitíssimas.

Os índios obtiveram licença para a administração dos sacramentos e esculpiram imagens para ornamentar a igreja que era constantemente reformada por eles. Nela havia uma bela imagem de São Nicolau, o santo católico que dera nome a um dos sete povos missioneiros e ao aldeamento guarani em Rio Pardo. Tais fatos demonstram que os índios possuíam experiências históricas na prática da religiosidade cristã e suas ações também eram pautadas por elas. No trecho supracitado, o arcediago parecia não considerar o passado dos índios e por algum motivo, suprimiu cerca de 50 anos de sua história, ao passar imediatamente do ano de 1812 para o ano de 1860 , como se nada tivesse ocorrido nesse intervalo, e como se a extinção do aldeamento decorresse apenas da perda da administração dos sacramentos. 
Por outro lado, é possível perceber que, involuntariamente, o religioso recuperou outros aspectos da história dos índios ao afirmar que, por volta de 1891 - ano de conclusão do Ementário - ainda viviam 'alguns descendentes' dos 'primitivos' moradores. Isso significa que a extinção do aldeamento pela Lei 1.114 de 1860 não levou, necessariamente, ao seu esvaziamento. Significa também que mesmo as histórias e obras mais escondidas e ocultadas, por serem consideradas 'imperfeitas' e 'inferiores' podem ter sua visibilidade garantida graças aos detalhes e às imprecisões das fontes históricas. Afinal, está na imperfeição do detalhe no qual o arcediago revelou que não haveria mais índios em São Nicolau do Rio Pardo, mas somente seus descendentes, pistas que conduzem ao indício da presença indígena no aldeamento no ano de 1891, cerca de 30 anos após sua extinção. Segundo o método de Giovanni Morelli, criado por volta de 1875 para devolver a autoria de obras de arte aos seus verdadeiros autores, é necessário não se basear em características comuns, como usualmente é feito, mas em características menos vistosas e, portanto menos imitáveis. Para Morelli, os pormenores mais passíveis de negligência eram reveladores justamente porque era algo que fugia do controle do artista. Carlo Ginzburg ressaltou o método morelliano de encontrar em detalhes, muitas vezes implícitos nas entrelinhas, indícios tão valiosos quanto o que parece ser óbvio: "Morelli propunha-se buscar no interior de um sistema de signos culturalmente condicionados, como o pictórico, os signos que tinham a involuntariedade dos sintomas (e da maior parte dos indícios, também involuntários)" (GINZBURG, 1989, p. 143-180).

As obras de arte esculpidas pelos indígenas de São Nicolau do Rio Pardo para colocarem na capela construída e reformada por eles foram postas na sacristia a revelia de seus criadores. Porém, como as obras de arte cujos autores Morelli encontrou para devolver-lhes a autoria, assim também é possível, pelo mesmo método, devolver, quiçá, outras obras de arte deixadas por esses índios guaranis: suas histórias de vida, sobretudo levando-se em conta os contextos e os eventos que fizeram com que eles se deparassem com situações limite, que punham à prova a sua sobrevivência física e étnica. A indigência e a miséria na aldeia são constantemente relatadas em outras fontes. 
A obra do arcediago Lopes é marcada por incorreções sobre dados e datas. Ademais, ele não demonstra ter melhor interesse e conhecimento sobre os índios do que os outros religiosos a quem critica no Ementário. Trata-se da involuntariedade dos sintomas e dos signos do paradigma indiciário discutido por Carlo Ginzburg. Segundo o arcediago, em outra passagem do manuscrito, em 1753, Gomes Freire de Andrade "[...] foi encarregado de acomodar índios Tapuias extraviados das missões" (EMENTÁRIO, [1891], p. 216). Os Tapuias ${ }^{11}$ são, segundo alguns discursos historiográficos e políticos do século XIX, índios selvagens que não passaram por experiências prévias de catequização, ao contrário dos índios missioneiros, a quem o arcediago se refere. De acordo com os referidos discursos os guaranis seriam enquadrados na categoria Tupis. Assim, mesmo tendo revelado repetidas vezes um grande desconhecimento sobre os índios a quem lastimava não ter conquistado, convertido e civilizado, a imperfeição dos seus escritos revela com certa perfeição a complexidade daquele contexto. Assim também, é possível perceber que os indígenas continuaram a ornamentar a igreja de São Nicolau, talvez numa tentativa de estabelecer relações sociais que lhes garantissem a permanência naquele território. Mesmo que suas imagens 'imperfeitas' estivessem na sacristia e não no altar da igreja construída por eles, o lugar ainda era ocupado pelos seus 'descendentes'. Os índios reconstruíram várias vezes sua capela e em diferentes locais do aldeamento. Ela simbolizava sua religiosidade cristã ${ }^{12}$. É importante salientar que, apesar da política de assimilação do Estado brasileiro, alguns grupos indígenas possuíam alguns direitos territoriais pautados, sobretudo, em suas identidades étnicas e culturais. Por isso, parecia ser fundamental manter vínculos e alianças com o Estado, com quem estavam em constante situação de conflito e negociação, e ao mesmo tempo, garantir que o sentido de sua identidade não fosse tomado como algo passível de ser assimilado em meio às políticas indigenistas, das quais a prática da catequese fazia parte. Por isso, é possível perceber o cuidado dos índios em manter viva a religiosidade cristã através do uso do espaço da igreja no aldeamento. Podemos dizer que tanto a religiosidade quanto a própria igreja foram reconstruídas pelos índios sempre que eles acharam necessário. Em alguns momentos, eles recuperam 
conhecimentos aprendidos no passado que faziam parte do seu presente, como os atos de esculpir santos católicos.

\section{Imagem 1: Esculturas Missioneiras.}

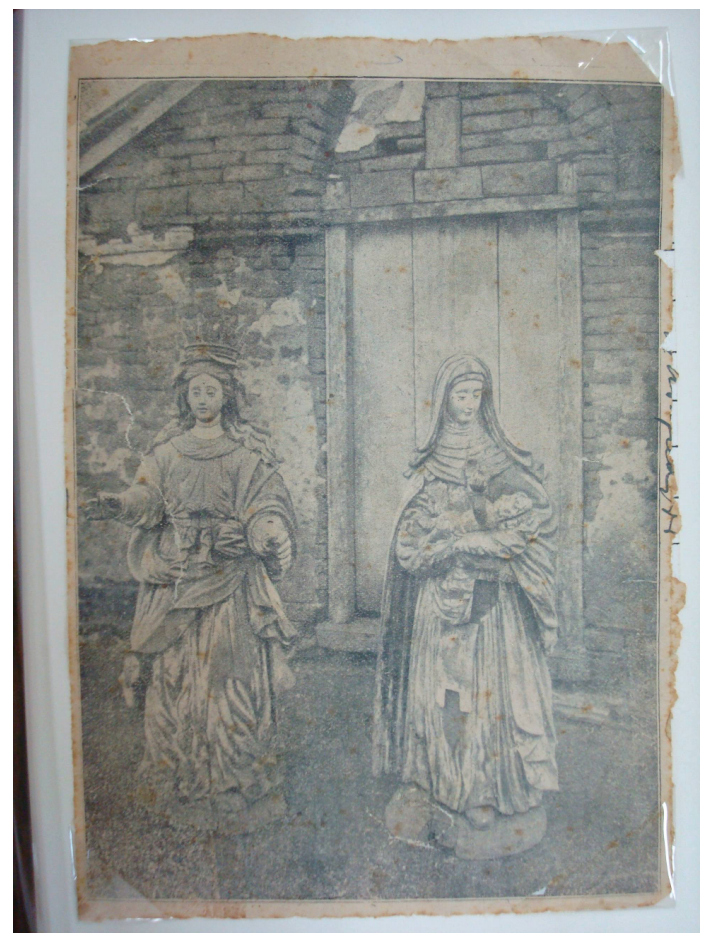

Fonte: AHRS, Fundo Iconografia, Pasta 50, Missões - 042.

O arcediago escolheu o tópico Catequese para encerrar o Ementário e relatou graves denúncias em tons de desabafo. Suas críticas tornam-se ainda mais contundentes quando se percebe que foram feitas baseadas em documentações eclesiásticas e oficiais consultadas. Ele escreveu sobre a chegada de missionários franciscanos, capuchinhos e jesuítas, sendo que dentre esses últimos se encontravam espanhóis, italianos e alemães. Também narrou, entre 1737 e 1863, as atividades desempenhadas pelos missionários e as 
medidas provinciais tomadas para que elas pudessem ser realizadas ou não. Segundo suas pesquisas e interpretações (EMENTÁRIO, [1891], p. 218-253):

Nesta Província nem antes nem depois de ser elevada a Bispado se tem cuidado da catequese dos indígenas com grande interesse, e por isso as Leis evangélicas não tem iluminado os filhos das selvas, que continuaram a servir sem instrução nem educação, habitando as florestas, e na maior ignorância, quando se podiam tornar úteis ao Estado se os civilizassem.

É interessante observar que, segundo as colocações do arcediago, ao contrário dos padres, os indígenas continuaram a servir ao Estado, mesmo habitando as selvas e não tendo a educação e a instrução consideradas necessárias à sua civilização, e, por conseguinte, à sua habilitação para prestar serviços úteis à nação. Entretanto, os missionários, mesmo sendo possuidores de todo o instrumental tido como necessário para civilizar os 'selvagens' - o conhecimento e a religião - optaram por morar na maioria dos casos longe da selva e longe dos 'selvagens', preferindo ensinar àqueles que já eram considerados 'civilizados'(Idem):

Todos estes sacerdotes enviados a pregar o Evangelho, aos selvagens, digno objeto de sua missão, contentaram-se a pregá-lo aos povos já civilizados. Desde então nenhum Sacerdote mais foi encarregado de pregar aos indígenas até 1842, em que chegaram em Porto Alegre os padres espanhóis da Companhia da Jesus, João Cori, Manoel Mattos e João Solanellas, os quais se restringiram a pregar na capital, em algumas Freguesias vizinhas, à convite dos povos.

Com essa ação, o trabalho dos missionários, mesmo sendo eles 'civilizados', não parece ter sido tão útil ao Estado quanto o dos índios. Além disso, nem todos os indígenas eram privados do acesso à instrução. Havia em São Nicolau do Rio Pardo uma escola para o ensino exclusivo de meninos guaranis, onde os mesmos aprendiam música, aritmética e língua portuguesa ${ }^{13}$. Assim, a utilidade 
dos indígenas na Província de São Pedro não parece ter dependido exclusivamente de sua 'civilização', pois mesmo habitando as matas e não tendo instrução, alguns deles continuaram a servir ao Estado. Em contrapartida, a maioria dos padres missionários, mesmo tendo vindo para tal e mesmo tendo a instrução necessária, optaram por não fazê-lo. Do mesmo modo, nem todos os indígenas 'civilizados' prestaram serviços ao Estado ou à Província, mas também para particulares. De qualquer forma, tanto os missionários quanto os índios pareciam estar cuidando de seus interesses, e de maneiras muito variadas. Ao passo que houve atitudes como as do padre Antônio de Almeida Leite Penteado, que "[...] ofereceu-se para levar aos toldos dos índios errantes pelas imediações de Passo Fundo os confortos da religião [...]" e "[...] cheio de fé percorreu alguns lugares onde havia selvagens, doutrinou-se, e [...] administrou-lhes os Sacramentos do Batismo e do Matrimônio [...]", houve também religiosos franciscanos que se limitaram a fundar "[...] um hospício e nunca de lá saíram" (EMENTÁRIO, [1891] p. 218-253). O padre Antônio Penteado afastou-se das atividades somente quando adoeceu. Não se sabe se ele esteve mesmo cheio de boas intenções com os índios para os quais se ofereceu a ir levar a religião católica, mas o certo é que suas atitudes foram tidas como apropriadas e condizentes com a missão dos padres na Província, segundo a opinião do arcediago Lopes. Entre as práticas que parecem ter sido comuns à catequese estão os trabalhos e as atividades religiosas vilipendiadas pelos missionários. Entre as particularidades, está o modo como cada religioso optou por deixar de lado as tarefas para as quais foram designados. Houve aqueles que fundaram hospícios e se internaram neles para não mais saírem, aqueles que excederam outras "faculdades" não condizentes aos impedimentos do matrimônio, quebrando o voto do celibato. Outros juntaram pecúlio e compraram imóveis, mesmo sendo proibidos de efetuar transações comerciais, como o capuchinho Fr. Caetano de Troina (Idem, p. 218-253):

Tendo comprado uma chácara no Arraial do Menino Deus próximo a Capela foi nela habitar, e por portaria de S. E. Rma., de 24 de julho de 1863, foi à Paróquia de Jaguarão substituir o distinto pároco Joaquim Rodrigues Lopes, que 
se oferecera a ir prestar serviços no Paraguai. Em poucos meses tornou ao Menino Deus, por terem os credores da pessoa em cujo nome tinha sido comprada a dita chácara tomado-a por dívida, visto que o proprietário como frade não podia fazer.

Houve ocasiões em que os religiosos encarregados pela presidência da Província de atividades como a visita aos aldeamentos, não a cumpriram por inteiro. É importante lembrar que na maioria destes casos, todas as despesas das atividades missionárias, realizadas ou não, eram cobertas pelos cofres da Província. Além disso, ao longo do século XIX, e sobretudo ao final dele, vários aldeamentos extintos foram espoliados por padres e autoridades políticas. Em 1885, por exemplo, a Câmara de vereadores de Porto Alegre recebeu uma correspondência do governador da Província do Rio de Janeiro, Cesário Alvim, pedindo auxílio para reunir objetos indígenas para serem remetidos ao Museu Nacional ${ }^{14}$. Por outro lado, nem sempre nobres intenções como parecem ter sido as do padre Antônio Penteado foram bem recebidas. $\mathrm{O}$ arcediago narrou um fato interessante que nos mostra o outro lado da moeda. Se as atitudes da maioria dos missionários pareciam ser questionadas pelas autoridades políticas e repudiadas por alguns religiosos, como foram recebidas as atitudes daqueles que queriam desenvolver com afinco as atividades que julgavam inerentes à sua missão?

Em 1846, apareceu na paróquia de Nossa Senhora do Rosário do Rio Pardo, "[...] um italiano trajando hábito preto cingido por um cordão branco, e aparentando espírito religioso e vida austera, era conhecido pelo nome de 'Monge"' (EMENTÁRIO, [1891], p. 44). Ele escolheu esta igreja matriz para fazer uma pregação. A permissão foi concedida pelo vigário, pelo provedor da irmandade e por outras pessoas da cidade. Porém, a experiência da pregação, ou a prática do discurso, não foi bem recebida pelos fiéis da paróquia quando o Monge (EMENTÁRIO, [1891], p. 45):

Subindo ao púlpito profanou o lugar santo, e usando de uma linguagem desaforada desacatou as famílias presentes, dirigindo-lhes palavras grosseiras. Descendo do púlpito, 
retirou-se, e estando distante da Igreja recebeu umas bengaladas em remuneração de tanto arrojo. Não mais voltou e foi habitar o cume do serro de Botucaraí, [n] uma ermida dedicada a Santo Antão, a qual era muito freqüentada pelas pessoas ignorantes, prontas em tudo crer, menos nas máximas e preceitos do Evangelho, e por muitos doentes vindos de vários lugares, dos quais alguns morreram, e outros voltaram do mesmo modo.

As atitudes do religioso italiano durante aquela missa foram responsáveis por severas punições que ele recebeu mais tarde. $\mathrm{O}$ 'Monge' foi agredido devido às palavras ditas por ele durante a homilia, um discurso acionado e usado para a pregação da prática cristã. Todavia, ele não desistiu daquilo que considerava ser a sua missão e foi morar entre os 'ignorantes' e doentes. O Botucaraí era um lugar para onde costumavam ir pessoas doentes em busca de cuidados e tratamentos, incluindo os índios de São Nicolau do Rio Pardo $^{15}$. Auguste Saint-Hilaire, conhecido cientista francês, viajou pela Província de São Pedro entre os anos de 1820 e 1821 e passou pela serra do Botucaraí. Ele registrou a existência de algumas aldeias de índios "mal vestidos" e lastimou que "[...] tanta gente deixe suas terras para se estabelecer aqui, onde cometem tantas extravagâncias pelas índias e não se enriquecem nunca" (SAINT-HILAIRE, 2002 [1820-1821], p. 393). Quanto ao 'italiano', tendo recebido algumas bengaladas, argumentou que se comunicava com os anjos, que o haviam aconselhado $\mathrm{a}$ ir àquele lugar. $\mathrm{O}$ 'Monge' parece ter feito amigos e inimigos fiéis, visto que ele foi ouvido por aqueles que estiveram 'prontos em tudo crer' e foi acolhido por pessoas ignorantes, doentes e indígenas na serra do Botucaraí. Mesmo assim, em 1848, foi mandado retirar de lá pelo presidente da Província “[...] por causa das imoralidades que resultaram da grande aglomeração de povo que [lá] ia a crescer, foi finalmente justiçado na Itália" (EMENTÁRIO, [1891], p. 45). Se o fim dos poucos religiosos que vieram para a Província de São Pedro e se interessaram pelo trabalho junto aos índios era adoecer em função dessas atividades, como no caso do padre Antônio Penteado, ou ser privado de realizar sua missão para ir a julgamento justamente por tentar cumpri-la, como no caso do 
'Monge', não é de se admirar que os demais missionários não tenham querido ir aos sertões, e sim optado por permanecer em hospícios, ou próximos aos diversos tipos de gabinetes (políticos e religiosos) dos centros urbanos.

Segundo o arcediago, aquele seria um esboço do que tinha havido sobre aldeamentos e catequese na Província desde o ano de 1737 até o ano de 1891, quando o Ementário foi concluído. Ele enfatizou que seus escritos foram extraídos de Relatórios de Presidente de Província e de outros documentos de arquivo (EMENTÁRIO, [1891], p. 218):

Neste esboço extraído dos Relatórios dos Presidentes da Província, e de documentos que se conservam nos arquivos, está tudo quanto tem havido a respeito de Aldeamentos e Catequese. Este estado lastimoso durará sem dúvida; e enquanto não houver providências, os filhos das selvas continuarão a viver nas trevas sem instrução, sem educação e sem civilização.

Ele se limitou a narrar os fatos extraídos das informações presentes na documentação, expressando-se nas entrelinhas. Entretanto, manifestou claramente sua opinião ao final do texto. Concluiu, categoricamente, que lastimava aquele estado de coisas, lamentava que o comentário histórico feito por ele desde 1737 sobre as atividades eclesiásticas do Rio Grande de São Pedro terminasse daquela maneira, sem alcançar seus objetivos. $\mathrm{O}$ arcediago escolheu encerrar os 154 anos da 'história eclesiástica' na Província do Rio Grande com o tópico Catequese. O final descrito por ele não foi feliz e revelou algo mais do que um simples desapontamento. Sua percepção dos fatos esteve ligada aos sentimentos de frustração, impotência e culpa. Mas, se esse discurso sobre a história do fracasso da catequese na Província é bastante enviesado, as escolhas feitas pelos padres missionários, oriundos de diferentes companhias religiosas, com interesses e histórias diversas, contribuíram para a sua conformação. Quanto ao final, que pode não ter sido assim tão infeliz para outros, não teria se configurado daquela forma se não fosse a participação dos índios, ainda que ela fosse vista pela maioria dos 
padres como um simples ato de não colaboração, decorrente de sua incapacidade de mudar.

Diante desse quadro, vale ressaltar que a história dos índios guaranis não terminou quando o aldeamento de São Nicolau do Rio Pardo foi extinto. As redes sociais que eles construíram são mais amplas do que se pensou e, como se pode notar, suas relações foram igualmente mais complexas, geraram tanto atos de solidariedade, como os do Monge e os das pessoas de Botucaraí quanto atos de força, como os das pessoas que o agrediram e o extraditaram. Esses atos contam suas histórias.

\section{Práticas indígenas nos discursos políticos}

Pode parecer estranho, mas nos relatórios de presidente da Província havia discussões sobre o extermínio dos índios e de seus aldeamentos na parte intitulada Catequese e Civilização. Apesar disso, tais relatórios indicam que houve um esforço, às vezes paradoxal e difícil de entender, por parte das autoridades provinciais, para civilizar os índios e torná-los 'amigos'. Sentimentos de repúdio e admiração estão presentes nessa documentação oficial. Em 1832, Luis Alves Leite de Oliveira Bello escreveu ${ }^{16}$ :

Pouco difere do ano passado o estado presente dos aldeamentos. Mas não faltarão esforços para dar algum incremento à sua população, e comodidade. É esse um dos serviços provinciais, a que, na minha opinião, se deve ligar muito interesse, não tanto pela conveniência de aditar-se a população da Província as hordas errantes, e selvagens de nossos colonos naturais, como pela necessidade de desinfetar as matas, e de converter em amigos, e membros úteis da sociedade os mais formidáveis inimigos de nossas populações centrais. Desistir do empenho em que já algumas somas se tem gasto pela pouca importância do resultado, seria perder o que se tem ganho, e perpetuar a luta desumana do cidadão com o selvagem. 
Trata-se de um discurso produzido num gabinete político, diferente de um discurso produzido nos gabinetes científicos situados na capital do Império. É interessante observar que, ao contrário dos discursos predominantemente difundidos pelos gabinetes científicos do Instituto Histórico e Geográfico Brasileiro (IHGB), neste caso, os índios não são admirados por fazerem parte de um passado remoto, como os Tupi ${ }^{17}$. O vice-presidente da Província refere-se aos índios do presente, os Tapuias, e os admira não pelo fato de eles serem exóticos, ou não vistos, mas pelo motivo oposto, visto que é o fato de ouvir sobre os índios, saber sobre ou ter que lidar com assuntos referentes a eles, quem sabe até mesmo conhecê-los, é que o fizeram pensar que eles eram "os mais formidáveis inimigos" e que é desumana a luta do cidadão com o selvagem. São as experiências vividas por ele que o fizeram sentir que não eram humanos os atos de força do 'civilizado' contra o 'selvagem'. A contradição presente entre os significados de sentimentos como a humanidade e a civilidade, e atos como os de selvageria são condizentes com a variada gama de pensamentos, experiências e sentimentos vividos pelos protagonistas dessa história. Segundo John Monteiro (MONTEIRO, 2001, p. 152):

[...] a tensão entre a simpatia pelos índios, frutos de experiências no sertão, e os pressupostos teóricos sobre a inferioridade e o atraso dos selvagens em referência à civilização se manifestava nos escritos de vários pensadores e políticos do Império.

Neste mesmo relatório, e dessa vez falando especificamente do aldeamento de São Nicolau do Rio Pardo, Luis Alves Leite de Oliveira Bello parece contradizer-se em relação aos índios da Província ${ }^{18}$ :

É a mais antiga aldeia da Província. Situada a pouca distância da cidade de Rio Pardo, e reduzida a 273 indivíduos de origem guarani, acha-se na maior decadência, e não conserva hoje nada, que se assemelhe ao registro das aldeias, a não ser um 
zeloso e honrado diretor. Os seus habitantes descendem todos de descendentes de índios catequizados.

Já não é possível perceber qualquer simpatia de Luis Bello por estes 'descendentes de índios catequizados'. Entretanto, trata-se de discursos diferentes sobre indígenas diferentes, ambos produzidos pela mesma pessoa e fazendo parte do mesmo relatório anual. Dentro desse discurso político, “os mais formidáveis inimigos de nossas populações centrais", os selvagens a quem Luis Alves Leite se refere, são os índios coroados. Os "indivíduos de origem guarani”, em cujo aldeamento não conserva nada que se assemelhe ao registro do que foram as aldeias guarani-missioneiras, são os guaranis do aldeamento de São Nicolau do Rio Pardo. É preciso levar em consideração que o passado dos guaranis é distinto do passado dos coroados e as ações direcionadas aos aldeamentos também são diferentes. Para o argumento que aqui desenvolvo, é necessário lembrar que os índios guarani-missioneiros das missões orientais do Uruguai estiveram envolvidos em negociações e conflitos, mediante os quais tiveram experiências de alianças e contatos estabelecidos ora com os jesuítas, ora com os portugueses e espanhóis, ora com seus 'compatriotas' brasileiros ao longo do tempo. Os índios Tupis, enquanto uma categoria inventada dentro dos gabinetes do IHGB, eram vistos como os nobres guerreiros que estabeleceram alianças com os portugueses no passado, inclusive alianças matrimoniais e de parentesco, garantindo aos lusitanos a conquista da terra brasilis. Entretanto, os índios guarani-missioneiros, que possuem um passado de alianças com os portugueses, e por esse motivo aproximam-se da categoria de índios Tupi nos discursos historiográficos do IHGB, são de ‘carne e osso' e estão presentes na Província de São Pedro durante todo o período imperial. Vale lembrar também que o aldeamento de São Nicolau do Rio Pardo foi fundado em virtude de uma negociação estabelecida entre os índios guarani-missioneiros e Gomes Freire de Andrade - o comissário português encarregado das demarcações de fronteira acordadas pelo tratado de Madri que, portanto, o passado de alianças com os portugueses não é tão remoto, nem tão fictício como para o caso da categoria inventada pelo IHGB (os Tupis). Em meio a essas confusões identitárias, em 
1857, o comendador Patrício Correa da Câmara escreveu de modo atrapalhado sobre a utilidade e a inutilidade dos índios de São Nicolau do Rio Pardo para a Província ${ }^{19}$ :

Acha-se este aldeamento bastante atrasado. Existem ali 264 indios, sendo 112 do sexo masculino, e 132 do sexo feminino, a maior parte velhos e aleijados das guerras nesta Província e no estado Oriental, o diretor queixa-se de que os moços sejam todos recrutados pelo Exército no que não lhe acho muita justiça, porque eles são pouco afeiçoados ao trabalho. O diretor pede a distribuição de alguma roupa, e ferramentas aos índios para a lavoura, pois que a sua indigência é extrema.

Por um lado, o comendador informava sobre a invalidez dos índios mais velhos em função das guerras civis e militares que houve na Província, atestando a prestação de serviços por parte dos mesmos, bem como sua 'utilidade' ao Estado. Por outro lado, insinuava que os jovens eram duplamente inúteis; primeiro, por não serem muito afeitos ao trabalho; segundo, por não poderem compor a povoação do aldeamento pelo fato de serem recrutados pelo Exército. Um ano mais tarde, apesar de desacreditado pelo comendador, o padre José Joaquim da Fonseca e Souza Pinto insistiu nos mesmos argumentos em outra carta enviada ao diretor geral dos índios ${ }^{20}$ :

Esta aldeia há muito que está lançada no esquecimento e a miséria nela é uma terrível verdade, seus povoadores são quase todos velhos e crianças, encontrando-se dentre aqueles muitos servidores ao Estado, que por sê-lo, se inutilizaram por ocasião da guerra civil nesta Província.

Índios guaranis possuíam marcas dos conflitos em seus corpos. Entre os homens idosos, havia inválidos e aleijados, devido à sua participação na guerra Farroupilha, como ficou conhecida a guerra regional de caráter republicano contra o governo imperial do Brasil ${ }^{21}$. Nesse sentido, e tendo em vista a quantidade de velhos e inválidos no aldeamento, será mesmo que aquele trabalho teria representado uma distração para eles? Para os jovens, ver naqueles 
idosos uma perspectiva daquilo que poderia vir a ser o seu futuro, certamente não tornava mais fácil o abandono do aldeamento para ir à guerra. Ademais, os discursos do político e do padre estão em discordância. Segundo o primeiro, os índios são inúteis. Segundo o padre e diretor de São Nicolau do Rio Pardo, os índios que outrora estiveram em 'idade produtiva' teriam se inutilizado, sendo úteis ao Estado. O que parece ter sido um choque de interesses políticos e territoriais para os governos imperiais e provinciais pode não ter sido assim tão contraditório para as políticas indígenas. A causa do estado decadente em que se encontrava o aldeamento não residia somente na dificuldade encontrada pelos políticos e religiosos em 'civilizar' os índios através dos métodos até então empregados, como a catequese, por exemplo, mas nos serviços militares prestados pelos índios. O esvaziamento do aldeamento em função da participação nas guerras contribuiu para a 'decadência' da agricultura no aldeamento, e consequentemente, para justificar apropriações das suas terras por terceiros alegando improdutividade e inaptidão dos índios para o trabalho. Mesmo assim, a participação dos índios nos conflitos não cessou. Tampouco impediu suas tentativas de manter o território do aldeamento. Isso demonstra que as opções de participar dos conflitos bélicos e lutar para manter a posse do território não se apresentaram como excludentes para os índios, como pensavam os políticos. Em primeiro lugar, os índios que lutavam para manter o território nem sempre eram os mesmos que atuavam nos conflitos. Em segundo, atuar nos conflitos poderia render títulos e posses de terras aos militares com bom desempenho, como parecia ser o caso de famílias guaranis do aldeamento de São Vicente. Tais famílias responderam negativamente ao pedido do presidente da Província sobre seus filhos atuarem em Corpos da Marinha, e positivamente em atuarem nos Corpos da Guarda Nacional "[...] logo que possam com o peso da espada ou da lança, como tem feito até o presente" 22 . Suas atitudes não foram vinculadas a aspectos deliberadamente culturais. Foram pautadas pelas suas trajetórias históricas, em que destacaram sua atuação constante nos conflitos, revelando que figuraram como parte integrante dos projetos políticos da Província. Suas reivindicações foram aceitas pelo governo. 
É perceptível que a participação dos índios nas guerras causava ferimentos que impossibilitavam trabalhos futuros e contribuía para o esvaziamento dos aldeamentos. Outras vezes, através do serviço nas frentes de batalha conseguiram construir memórias sobre sua atuação histórica em conflitos militares. A partir disso, conquistaram novos territórios, prestígio político e certa ascensão social, como aconteceu no caso de famílias guaranis do aldeamento de São Vicente. Outros relatórios e correspondências encaminhadas e recebidas por autoridades da Província não deixam dúvidas sobre o quão importante foi a participação dos índios na guerra dos Farrapos. Contraditoriamente, nem sempre essa participação foi vista com bons olhos. Ao escrever sobre assuntos de agricultura e comércio o diretor geral dos índios, o barão do Triunfo, informou ao Ministro do Império brasileiro sobre os guaranis aldeados da Província de São Pedro: “[...] estes índios são bons soldados, e peões, viviam também de conduzir tropas para as charqueadas e de trabalharem nelas, donde tiravam recursos" $" 23$. Do maior aldeamento guarani da referida Província “[...] foram tirados muitos braços, [...] e poderá ainda dali sair para o exército muitos bons soldados como já aconteceu" 24 . De modo geral, no conjunto documental analisado, chama atenção a ausência de homens em 'idade produtiva' no aldeamento ao longo do tempo, o que pode indicar que naquele e em outros momentos os índios estivessem constantemente participando do serviço militar e trabalhando como peões em estâncias, demonstrando que essas atividades podem ter sido úteis para a sua sobrevivência naquele contexto (MELO, 2011). O conteúdo de fontes como as supracitadas demonstra também a mobilidade espacial de alguns índios com as idas e vindas dos aldeamentos em virtude das excursões militares. Esse é um dos motivos pelos quais a maior parte da população de São Nicolau do Rio Pardo era composta por velhos, mulheres e crianças. No ano de 1859, outro político dizia o seguinte ${ }^{25}$ :

Não sou dos que acreditam na proficuidade dos meios atualmente empregados para chamar à civilização as tribos errantes, que habitam as nossas florestas, e imprimir-lhes hábitos de vida mais regulares e pacíficos. Em toda parte sentem-se os mesmos embaraços, e atuam as mesmas 
causas, que explicam o estado pouco satisfatório dos nossos aldeamentos. Sem missionários apostólicos não há catequese possível. Dificultosa se tem tornado a aquisição deles, e sem esperança de consegui-los na proporção das nossas necessidades, confio ainda menos na sorte futura das nossas colônias indígenas.

Já nesse discurso, pode-se observar que, inúteis são os meios empregados em toda parte para catequizar e 'civilizar' os índios. A opinião desse político, o conselheiro Joaquim Antão Fernandes Leão, está, de certo modo, em consonância com a opinião daquele padre, o arcediago Lopes, no tocante à ineficiência da catequese como um dos métodos mais utilizados pela Província na civilização dos índios. Ambos comentaram a carência de missionários naquele período, por mais que, como vimos, a chegada de mais religiosos não significasse, necessariamente, o suprimento das demandas da catequese na Província. Além disso, havia outras questões referentes à política indigenista. Até meados do século XIX, a tônica do projeto indigenista era referendada pelas diretrizes assimilacionistas do projeto pombalino. Mas havia aspectos da política indigenista do Oitocentos que eram distintas das disposições presentes no Diretório dos Índios. Enquanto este previa a assimilação e a integração dos indígenas através da persuasão e do convencimento, aquela abria precedentes legais para uma série de atrocidades contra os índios. Havia expedições organizadas para matar índios 'selvagens' e ou não aldeados. Através de processos que Manuela Carneiro da Cunha chamou de "políticas de intrusamento" e "políticas de concentração" aos índios eram oferecidas poucas e já conhecidas opções: a cruz ou a espada, ou seja, a conversão através da catequese nos aldeamentos ou o extermínio (CUNHA, 1992, p. 142-143). Essa frase pode parecer um pouco forte, mas de fato houve em todo o Brasil, durante o século XIX, o que poderíamos entender como políticas públicas de extermínio dos índios tidos como 'selvagens' ou 'não civilizados'. Quando ‘as partidas ou correrias de índios' não eram feitas por particulares, as chamadas Companhias de Pedestres eram encarregadas e pagas pelo governo provincial para deixar as matas e os colonos livres dos índios. Na Província de São Pedro não era 
diferente. Pouco tempo depois do estabelecimento da lei de Terras em 1850, o vice-presidente da Província relatava ${ }^{26}$ :

O sistema da força, e o da persuasão que se tem empregado separadamente para tirar das matas os nossos indígenas, tem sidos ambos improfícuos. Até aqui nos temos limitado a: $1^{\circ}-$ a atrair os índios por meio de algumas roupas, e ferramentas distribuídas nas aldeias de Nonohay e Guarita, e a conservá-los ali pelos esforços dos padres jesuítas; de catequisação propriamente dita pouco se tem feito, sem dúvida porque aqueles padres ignoram a língua, em que deveriam dirigir aos índios as palavras de conversão; $2^{\circ}-$ a bater os índios, perseguí-los, e matá-los, quando eles têm feito alguma agressão, e a colocar guardas por algum tempo nos lugares que eles têm agredido. Pela simples enunciação se vê que esses dois sistemas são incompletos, e a experiência os têm condenado. Os índios recebem as roupas, e as ferramentas, e voltam às matas; batidos e perseguidos depois da agressão, reaparecem mais hostis em outros lugares, não sendo possível colocar guardas em todos aqueles por onde fazem seus assaltos.

Perseguir e matar os índios foi uma política de violência praticada física e simbolicamente. Enquanto alguns indígenas, como aqueles que faziam parte do aldeamento de São Nicolau do Rio Pardo, buscavam manter relações sociais levando em conta o seu passado, e tentando resgatar a importância das alianças estabelecidas ao longo dos últimos cem anos, o comendador Patrício Câmara parecia ter pressa do futuro e do que chamou de "a marcha providencial dos acontecimentos”. Em 1861, ele voltava a ser o responsável pelo relatório da presidência da Província e sobre a catequese e a civilização dos índios escreveu ${ }^{27}$ :

Ao falar pela primeira vez desse assunto malfadado para todas as administrações do país, disse eu à Assembléia Provincial que tinha tristes previsões do futuro dos aldeamentos da Província. A ninguém é lícito apressar a marcha 
providencial dos acontecimentos; entretanto tem-se querido obter das tribos errantes do sertão uma transição demasiado rápida dos seus hábitos de ociosidade, para os penosos trabalhos da agricultura, que em todas as épocas caracterizam um estado social já adiantado: nada se tem conseguido, nada provavelmente se há de conseguir. A própria natureza protesta contra o sistema até hoje aceito. Quantos milhões de indivíduos tem já sucumbido ao peso desses progressos fictícios que se lhes impõe?

Os índios demonstravam que possuíam uma história e que a conheciam, por exemplo, ao reformar constantemente sua igreja, ou ao enviar requerimento baseados em direitos e concessões adquiridas no passado, como fizeram Miguel Guarací e lavradores de São Nicolau do Rio Pardo ${ }^{28}$. Em seu discurso, o comendador tentava negar a possibilidade de continuidade da mesma. Ele considerava a transição dos indígenas da selvageria à civilização demasiadamente lenta, afinal, fazer com que os índios fossem capazes de mudar tão rapidamente era esperar demais deles. Conseguir que deixassem seus hábitos ociosos e atingissem o que ele considerava ser um estágio social avançado, era quase uma experiência onírica, era um futuro impossível de ser concretizado na realidade vivida pelos índios e, portanto, era um futuro possível de ser vislumbrado apenas no mundo dos sonhos. A despeito de seu prognóstico nada animador sobre a civilização e o futuro dos índios, o comendador fez uma pergunta capaz de encabular até mesmo o mais insensível e descomprometido dos políticos de todos os tempos: “[...] quantos milhões de indivíduos tem já sucumbido ao peso desses progressos fictícios que se lhes impõe?". Nesse discurso político em que se faz presente o confronto entre ficção e realidade, não são somente os índios mortos e os progressos do século XIX que transitam entre fronteiras complexas de atos, ideias e sentimentos. A violência contra os índios selvagens e a dificuldade da política indigenista em civilizá-los também aparecem misturadas. Sem responder à pergunta capciosa e imprevisivelmente atual que havia feito, o comendador passou a tratar especificamente do aldeamento de São Nicolau do Rio Pardo ${ }^{29}$ : 
Falarei sobre esse tópico por ser ainda conservado um diretor estipendiado pelos cofres provinciais. Em o último relatório que apresentei, disse o que era realmente este aldeamento, ao qual me parece que pode ser aplicada a disposição do $\$$ $8^{\circ}$ do art. 11 da lei $n^{\circ} 1.114$ de 27 de setembro de 1860 , e $\int$ $4^{\circ}$ do art. $1^{\circ}$ do decreto ${ }^{\circ} 426$ de 24 de julho de 1845.

Este relatório foi escrito no ano de 1861. Conforme destacado anteriormente, há pouco mais de um século antes disso, em 1757, o aldeamento de São Nicolau do Rio Pardo era fundado depois do acordo feito entre guarani-missioneiros e portugueses durante um evento marcante na história das demarcações fronteiriças na região - a Guerra Guaranítica (1754-1756). Em 1757, 1758 e 1759, cerca de cem anos antes desses relatórios de políticos terem sido escritos, havia índios estabelecidos em São Nicolau do Rio Pardo e índios que continuavam a chegar e a partir. Percebe-se claramente que, em 1861, quando o comendador Patrício Câmara escreveu o relatório, São Nicolau do Rio Pardo ainda representava uma possibilidade de sobrevivência para alguns índios. Em 1862, o desembargador Francisco de Assis Pereira Rocha informou ${ }^{30}$ :

Os índios da raça guarani que ainda permanecem na aldeia de São Nicolau em número de 85 homens e 115 mulheres, com exceção de 12 que se empregam nos trabalhos da lavoura, os mais vivem em completa ociosidade, ou à espera de alguém que os procure para se empregarem como peões.

Mesmo depois de anunciada a sua extinção, índios permaneciam no aldeamento trabalhando na lavoura ou à espera de emprego como peões de estância. É possível que outros ainda estivessem prestando serviços militares. Nota-se que ao longo de cem anos o modo de ser e se relacionar dos indígenas mudou, assim também como mudaram os significados da luta pela ocupação daquele espaço. Haviam negociado com autoridades do governo no período de formação do aldeamento e estabelecido conflitos contra elas no período de sua extinção. Mesmo depois de ter passado por tantas mudanças, São Nicolau do Rio Pardo continuava a ser um espaço capaz de congregar 
índios vindos de vários lugares. Dados quantitativos sobre a escola do aldeamento nos anos de 1848, 1854 e 1865 trazem informações sobre alunos vindos das 'Missões', do 'Estado Oriental', do distrito do Couto, São José do Patrocínio, Santo Amaro, Viamão, Santana do Livramento, São Gabriel, Itaquí e São Leopoldo ${ }^{31}$. Eles revelam um intenso deslocamento espacial dos índios durante o contexto de extinção do aldeamento. Tal mobilidade contribuiu para mudar o prognóstico sobre o futuro do aldeamento e dos índios feito por políticos ${ }^{32}$ :

Sua população consta atualmente de 234 indivíduos da raça guarani, sendo homens 103 e mulheres 131; notando-se do mapa anterior, para mais de 18 homens e 16 mulheres. Não declarando o diretor geral de onde proveio esse aumento de população, nem em qual dos ramos de indústria se emprega, reporto-me ao que anteriormente se tem dito a respeito. Cabe aqui informar-vos que, tendo-se solicitado do Governo Imperial, pela secretaria do Estado dos Negócios da Agricultura, Comércio e Obras Públicas, a concessão das terras pertencentes a essa aldeia, a fim de estabelecer-se nela a colônia agrícola, de que trata a Lei Provincial no 493 de 11 de janeiro de 1862, foi declarado por aviso daquele Ministério de 29 de dezembro último, que por hora não podia ser atendido aquele pedido.

Esse foi o último relatório de presidente da Província sobre os índios de São Nicolau do Rio Pardo, feito por Espiridião Eloy de Barros Pimentel, em 1863. Entretanto as fontes apontam para indícios sobre sua presença mais tardia no aldeamento, como vimos no Ementário. Isso mostra que se posicionaram e foram capazes de atuar, mesmo que alguns dos discursos proferidos vinculassem sua imagem à de índios do passado que estavam em vias de extinção. Eles fizeram parte daquele presente e suas atuações não passaram incólumes pelo tempo. Suas ações são fatos reais e fazem parte da história e da cultura indígena e sul-rio-grandense. 


\section{Considerações finais}

As atuações dos índios na Província de São Pedro fizeram parte de muitas histórias e de alguma maneira elas se manifestaram nos discursos produzidos sobre eles. Para além da tendência presente nos

$\infty$ discursos de políticos e religiosos sobre os índios no Brasil do século XIX, - que ora os invisibilizou, ora os incapacitou, ora os enalteceu - nas suas entrelinhas, encontram-se informações desconhecidas sobre as práticas desses agentes sociais. Eles atuaram ativa e diferentemente em prol de seus interesses. Guaranis de São Nicolau do Rio Pardo exerceram atividades militares durante a Guerra dos Farrapos, movimentaram-se pelo território da Província, receberam aulas na escola do aldeamento, trabalharam como peões de estância, reconstruíram e ornamentaram sua igreja sempre que julgaram necessário. Em algumas situações, obtiveram benefícios com a prática da religiosidade cristã. Em outras, alcançaram notoriedade e reconhecimento pelos serviços militares prestados. Também foram tratados com violência, como no caso dos índios coroados de Guarita e Nonoai. Sofreram com os efeitos das políticas indigenistas e das improbidades administrativas nos aldeamentos e gabinetes políticos e eclesiáticos. Apesar disso, reelaboraram suas identidades e construíram relações sociais mais amplas e importantes do que se pensou. As maneiras com que se posicionaram geraram atos de solidariedade, admiração, desprezo e força por parte dos políticos e religiosos. Todas essas experiências de mobilidade, trabalho e sociabilidade fazem parte de histórias perdidas nas fronteiras entre a realidade e a ficção presentes nos mais diversos discursos produzidos sobre os índios no sul do Brasil. Ambos, a história e os discursos, demonstram que as práticas indígenas geraram registros reveladores do protagonismo desses agentes. O conhecimento sobre elas é fundamental para dar a ver a existência de um passado mais rico e de uma história mais real.

\section{THE INDIANS IN THE PROVINCE OF SAINT PETER: BETWEEN PRACTICES AND SPEECHES}

Abstract: This article raises important issues about the historical processes that the indigenous people of the Province of St. Peter lived, taking into account 


\section{Karina Moreira Ribeiro da Silva e Melo}

some of the speeches that were produced by such stories and their agents. The speeches of politicians on them seem to be contradictory, but show the difficulty of those who wrote both in dealing with indigenous policy and with the Indian policy. Different, though marked by some similarities, the religious discourse show the challenge that the practice of catechesis represented to them and the Indians. There were quite distinct reasons for such actions, revealing that the individual and collective experiences of Indians, politicians and missionaries led to important conflicts and alliances in the stories of these characters.

Keywords: Province of St. Peter. Indians. Political authorities. Missionaries. Practices and speeches.

\section{Notas}

${ }^{1}$ Para maiores detalhes sobre esse debate acerca das noções sobre Tupie Tapuia ver MONTEIRO, John Manuel. Tupis, tapuias e historiadores. Estudos de bistória indigena e do indigenismo. Tese apresentada para o concurso de Livre Docência em Antropologia na Universidade Estadual de Campinas, Campinas, 2001, com destaque para o Capítulo 8: As "Raças" Indígenas no Pensamento Brasileiro, p. 170-179. ${ }^{2}$ Ver Capítulo 7, Entre o Gabinete e o Sertão: Projetos Civilizatórios, Inclusão e Exclusão dos Índios no Brasil Imperial, p. 129-169.

${ }^{3}$ AHPA. Relatórios de Presidente da Província de São Pedro do Rio Grande do Sul, Catequese e Civilização dos Índios entre 1832, 1857, 1859, 1861, 1862, 1863. ${ }^{4}$ IHGRGS. LOPES, Vicente Zeferino Dias. "Comentário Eclesiástico do Rio Grande de São Pedro do Sul desde 1737”. Cópia datilografada. Agradeço a Fábio Kühn por ter cedido a mim uma cópia desse documento. Daqui em diante, esta obra será referenciada como Ementário [1891].

${ }^{5}$ AHRS, Fundo Indígenas. Diretoria Geral dos Índios e dos Aldeamentos, maços 2 e 3.

${ }^{6} \mathrm{O}$ Correio do Povo é um jornal impresso brasileiro em formato tablóide com circulação no estado Rio Grande do Sul fundado em $1^{\circ}$ de outubro de 1895, por Caldas Júnior. Foi o jornal de mais longa publicação em Porto Alegre, circulando por 89 anos ininterruptamente, até 1984, reiniciando sua publicação em 1986.

${ }^{7}$ De acordo com Fábio Kühn, “O padre Vicente Zeferino Dias Lopes nasceu em Itaboraí, então província do Rio de Janeiro, no ano de 1818. Logo após ter sido ordenado, foi enviado como pároco de Viamão (1843-1847). Em seguida, tornouse vigário em Rio Pardo, exercendo esta função entre 1847 e 1851. Com a criação do bispado do Rio Grande do Sul, passou a fazer parte do Cabido catedralício, tendo sido nomeado arcediago através de decreto imperial de 16.07.1862 (Rubert, 
1998, p. 22, 26, 212). [...] O referido manuscrito - hoje disponível na forma de uma cópia datilografada - constitui um repositório importante de informações sobre a história eclesiástica do Rio Grande do Sul, não obstante algumas eventuais incorreções”. KÜHN, Fábio. “Um corpo, ainda que particular”: irmandades leigas e Ordens Terceiras no Rio Grande do Sul colonial', In: História Unisinos,. v. 14 n. 2 - maio/ago. de 2010, p. 126. Disponível em: <http://www.unisinos. br/publicacoes_cientificas/images/stories/pdfs_historia/vol14n2/art02_kuhn. pdf $>$. Acesso em 17 de fev. 2011.

${ }^{8}$ JORNAL CORREIO DO POVO, em Obras Inéditas Sobre o Rio Grande do Sul, de Paranhos Antunes, aos 22 de setembro de 1956.

${ }^{9}$ Os trechos e citações desta página e da anterior foram extraídas da sobredita matéria publicada no jornal Correio do Povo.

${ }^{10}$ Os grifos estão presentes na cópia datilografada do manuscrito.

${ }^{11}$ Para maiores detalhes sobre as concepções da época sobre as categorias inventadas de Tupis e Tapuias, ver MONTEIRO, John Manuel. Op. Cit. 2001, com destaque para o capítulo 9, Tupis, Tapuias e a História de São Paulo: Revisitando a Velha Questão Guainá, p. 180-193.

${ }^{12}$ Sobre outros índios cristãos, ver CARVALHO, Jr. Almir Diniz de. Índios cristãos: a conversão dos gentios na Amazônia portuguesa (1653-1769). Campinas: 2005. Tese (Doutorado).

13 AHRS. Fundo Instrução Pública, Documentação avulsa, maço 13, cx. 6.

${ }^{14}$ AHPA - Correspondência passiva da Câmara de Vereadores de Porto Alegre. Livro n. 40. 30 de abril de 1885.

${ }^{15}$ AHRS. Fundo Indígenas. Diretoria de Geral dos Índios. Aldeia de São Nicolau. Correspondência ativa de José Joaquim de Andrade Neves, maço 3, 1849.

${ }^{16}$ AHPA. Relatório do Vice-Presidente da Província de São Pedro do Rio Grande do Sul, Luiz Alves Leite de Oliveira Bello, na abertura da Assembleia Legislativa Provincial, 01 de outubro de 1832.

${ }^{17}$ Menciono a dicotomia entre Tupis e Tapuias tendo como referência a análise feita por John Monteiro ao longo da sua tese de livre docência. MONTEIRO, John Manuel. Op. Cit. 2001.

${ }^{18}$ AHPA. Relatório do Vice-Presidente da Província de São Pedro do Rio Grande do Sul, Luiz Alves Leite de Oliveira Bello, na abertura da Assembleia Legislativa Provincial, 01 de outubro de 1832.

${ }^{19}$ AHPA. Relatório do Vice-Presidente da Província de São Pedro do Rio Grande do Sul, Patrício Correa da Câmara, na abertura da Assembleia Legislativa Provincial, 01 de outubro de 1857.

${ }^{20}$ AHRS, Correspondência ativa José Joaquim da Fonseca e Souza Pinto; José Joaquim de Andrade Neves. Diretoria Geral dos Índios, maço 4, março de 1858. 
${ }^{21}$ A pesquisa que realizo sobre a atuação dos índios guaranis na Guerra dos Farrapos iniciou-se nos últimos anos de minha graduação, em 2008 e 2009. Quando visitei os arquivos históricos de Porto Alegre à procura das histórias dos guaranis no século XIX, deparei-me com um considerável conjunto documental sobre o aldeamento de São Nicolau do Rio Pardo. Ele foi o maior e mais duradouro aldeamento guarani da história do Rio Grande do Sul. Também chamou a atenção o fato de constar nas fontes as reiteradas participações desses índios nas guerras provinciais, sobretudo a guerra Farroupilha. Esse tema foi desenvolvido no capítulo intitulado Sobre guerras e guaranis em tempos provinciais da minha dissertação de mestrado, defendida no Programa de Pós-Graduação da Universidade Federal do Rio Grande do Sul (UFRGS), em 2011. Este mesmo tema também faz parte da pesquisa que atualmente desenvolvo junto ao Programa de Pós-Graduação em História Social no curso de doutorado na Universidade Estadual de Campinas (Unicamp).

${ }^{22}$ AHRS, Correspondência ativa de Manuel Pires Leis; José Joaquim de Andrade Neves. Diretor da Aldeia de São Vicente, maço 2, 1859. Distrito de São Vicente. 2 de setembro de 1858.

${ }^{23}$ AHRS, Fundo Indígenas. Diretoria Geral dos Índios, maço 3. Correspondência Ativa José Joaquim de Andrade Neves, 01 de janeiro de 1850.

${ }^{24}$ AHRS, Fundo Indígenas. Diretoria geral dos Índios, maço 3. Correspondência ativa José Joaquim de Andrade Neves, 01 de janeiro de 1849.

${ }^{25}$ AHPA. Relatório do Vice-Presidente da Província de São Pedro do Rio Grande do Sul, Joaquim Antão Fernandes Leão, na abertura da Assembleia Legislativa Provincial, 1859.

${ }^{26}$ AHPA. Relatório do Vice-Presidente da Província de São Pedro do Rio Grande do Sul, Patrício Correa da Câmara, na abertura da Assembleia Legislativa Provincial, 1861. ${ }^{27}$ AHPA. Relatório do Vice-Presidente da Provincia de São Pedro do Rio Grande do Sul, Luiz, Alves Leite de Oliveira Bello, na abertura da Assembleia Legislativa Provincial, 01 de outubro de 1852.

${ }^{28}$ Biblioteca Nacional do Rio de Janeiro, $I I-35,36,1$ n. 7. Guaraci, Miguel e outros. Pedem, o capitão-mor e outros lavradores, da aldeia de São Nicolau, na vila do Rio Pardo (RS), seja respeitada a concessão recebida há cinquenta anos, do privilégio da plantação e preparo da erva-mate. Aldeia de São Nicolau, 1823. Agradeço a Elisa Garcia, por ter cedido a mim a transcrição deste documento. ${ }^{29}$ AHPA. Relatório do Vice-Presidente da Província de São Pedro do Rio Grande do Sul, Patrício Correa da Câmara, na abertura da Assembleia Legislativa Provincial, 1861. ${ }^{30}$ AHPA. Relatório do Vice-Presidente da Província de São Pedro do Rio Grande do Sul, Francisco de Assis Pereira Rocha, na abertura da Assembleia Legislativa Provincial, 1862. 
${ }^{31}$ AHRS. Fundo Instrução Pública, maço 13, cx. 6. Mapa dos Alunos que frequentam aula pública de Primeiras Letras de São Nicolau [1848, 1854, 1865].

${ }^{32}$ AHPA. Relatório do Vice-Presidente da Província de São Pedro do Rio Grande do Sul, Eloy de Barros Pimentel, na abertura da Assembleia Legislativa Provincial, 1863.

\section{Locais de Pesquisa e Fontes Consultadas:}

Arquivo Histórico de Porto Alegre (AHPA). Relatório do Vice-Presidente da Província de São Pedro do Rio Grande do Sul, Patrício Correa da Câmara, na abertura da Assembleia Legislativa Provincial [1857, 1859, 1861].

Arquivo Histórico do Rio Grande do Sul (AHRS); Fundo Estatística. Livro de estatística judicial dos juizados de paz (1830-1844). Mapa estatístico das conciliações propostas pelos juizados de paz de Rio Pardo. Maço 1, 1833; Fundo Instrução Pública, maço 13, cx. 6. Mapa dos Alunos que frequentam aula pública de Primeiras Letras de São Nicolau [1848, 1854, 1865]. Diretoria Geral dos Índios. Correspondência ativa: José Joaquim de Andrade Neves, 01 de janeiro de 1849; Fundo Indigenas. Diretoria Geral dos Índios. Correspondência ativa: José Joaquim de Andrade Neves, maio de 1850; Correspondência ativa de Manuel Pires Leis; José Joaquim de Andrade Neves. Diretor da Aldeia de São Vicente, maço 2, 1859. Distrito de São Vicente, 2 de setembro de 1858; Correspondência ativa José Joaquim da Fonseca e Souza Pinto; José Joaquim de Andrade Neves. Diretoria Geral dos Índios, maço 4, março de 1858.

Biblioteca Nacional do Rio de Janeiro (BNRJ) Tomo II - 35, 36, 1 n. 7.

Instituto Histórico e Geográfico do Rio Grande do Sul (IHGRGS). DIAS LOPES, Vicente Zeferino. "Comentário Eclesiástico do Rio Grande de São Pedro do Sul desde 1737” [1891]. Cópia datilografada. Caixa D, nº 10.

\section{Referências}

ALMEIDA, Maria Regina Celestino de. Metamorfoses indigenas: identidade e cultura nas aldeias coloniais do Rio de Janeiro. Rio de Janeiro: Arquivo Nacional 2003. . Comunidades indígenas e Estado nacional: histórias, memórias e identidades em construção (Rio de Janeiro e México - séculos XVIII e XIX). In: 


\section{Karina Moreira Ribeiro da Silva e Melo}

ABREU, Martha; SOIHET, Rachel; GONTIJO, Rebeca (Org.). Cultura politica e leituras do passado: historiografia e ensino de história. Rio de Janeiro: Civilização Brasileira, 2007, p. 192-212.

BOCCARA, Guillaume. Memoria Americana. Cuadernos de Etnobistoria. Génesis y estructura de los complejos fronterizos euro-indígenas, repensando los márgenes americanos a partir (y más allá) de la obra de Nathan Wachtel. Buenos Aires. n. 13. 2005.

CARVALHO, Jr. Almir Diniz de. Índios cristãos: a conversão dos gentios na Amazônia portuguesa (1653-1769). Campinas, 2005. Tese (Doutorado).

CUNHA, Manuela Carneiro da. Política Indigenista no século XIX. In: História dos indios no Brasil. São Paulo: Companhia das Letras, 1992.

GARCIA, Elisa Frühauf. As diversas formas de ser do indio: políticas indígenas e políticas indigenistas no extremo sul da América Portuguesa. Niterói, PPG-História/ UFF, Tese de Doutorado, 2007.

GINZBURG, Carlo. Mitos, Emblemas, Sinais. São Paulo, Cia das Letras, 1989.

GRIJÓ, Luis Alberto; NEUMANN, Eduardo Santos (Org.). Continente em armas: uma história da guerra no sul do Brasil. Rio de Janeiro, Apicuri, 2010.

HILL, Jonathan D. (Org). History, power and identity: ethnogenesis in the Americas, 1492-1992. Iowa City: University of Iowa Press, 1996.

KÜHN, Fábio. Um corpo, ainda que particular: irmandades leigas e Ordens Terceiras no Rio Grande do Sul colonial', in História Unisinos,. v. 14, n. 2, maio/ ago. 2010, p. 126.

MELO, Karina M. R. da Silva e. A Aldeia de São Nicolan do Rio Pardo: histórias vividas por indios guaranis (séculos XVIII-XIX). Dissertação (Mestrado em História). Universidade Federal do Rio Grande do Sul, 2011.

MONTEIRO, John Manuel. Tupis, tapuias e historiadores. Estudos de bistória indígena $e$ do indigenismo. Tese apresentada para o concurso de Livre Docência em Antropologia na Universidade Estadual de Campinas, Campinas, 2001.

NEUMANN, Eduardo Santos. Práticas letradas guarani: producão e usos da escrita indígena (séculos XVII e XVIII). Tese (Doutorado em História). Universidade Federal do Rio de Janeiro, 2005.

RIBEIRO, José Iran. "Nem oficiais, nem soldados: perfis dos militares de patentes intermediárias do Exército Imperial brasileiro durante a Guerra dos Farrapos" in Lócus: revista de História, Juiz de Fora, v. 15, n. 2, 2009, p. 110. Dossiê Saúde: profissões, ciências e políticas públicas. 
Os indígenas na província de São Pedro...

SAINT-HILAIRE, Auguste. Viagem ao Rio Grande do Sul (1820-1821). Tradução de Adroaldo Mesquita da Costa. 2. ed. Porto Alegre: Martins Livreiro, 1987.

SIDER, Gerald. Identity as History, Ethnohistory, Ethnogenesis and Ethnocide in the Southeastern United States. Identities Global Studies in Culture and Power. New Hampshire, v. 1, 1994.

WILDE, Guillermo. Religión y poder en las misiones de guaraníes. Buenos Aires: SB, 2009.

Recebido em: 30/10/2011.

Aprovado em: 17/01/2012. 